\title{
Ambient Noise in Emergency Rooms and Its Health Hazards
}

\author{
Walderes Filus ${ }^{1} \quad$ Adriana Bender Moreira de Lacerda $^{1}$ Evelyn Albizu ${ }^{2}$ \\ 1 Program in Communication Disorders, Universidade Tuiuti do Paraná, \\ Curitiba, Paraná, Brazil \\ 2 Occupational Safety Engineer, Fundacentro, Curitiba, \\ Address for correspondence Adriana Bender Moreira de Lacerda, PhD, \\ Universidade Tuiuti do Paraná, Rua Sidney Lima Santos 238 238, \\ Curitiba, Paraná 82.010-330, Brazil (e-mail: adri.lacerda2@gmail.com).
} Paraná, Brazil

Int Arch Otorhinolaryngol 2015;19:205-209.

\begin{abstract}
Introduction The occupational risk due to high levels of noise in the hospital environment has been recognized, and the National Agency of Sanitary Surveillance of the Ministry of Health recommends evaluation and control of noise in hospital areas. Objectives To assess the sound environment in the emergency ward of a general trauma reference hospital in the city of Curitiba, Parana State, Brazil.

Methods In this descriptive study, noise levels were assessed on mornings, afternoons, and evenings using an integrating Bruel \& Kjaer (Denmark) calibrated sound level meter, type 2230. Ten indoor points in the emergency ward were assessed; the helicopter as well as several available pieces of equipment in the ward were assessed individually.

Results Noise levels in sound pressure level ambiance [dBA] ranged from 56.6 to 68.8 . The afternoon period was the noisiest. The helicopter at $119 \mathrm{dBA}$ and the cast saw at 90 $\mathrm{dBA}$ were the noisiest equipment, and the lowest noise level found was the activated oximeter at $61.0 \mathrm{dBA}$.

Conclusion In all assessed points, noise levels were above the comfort levels recommended by the Brazilian Association of Technical Standards (1987), which may harm

Keywords

- noise

- emergency medical services

- occupational noise users' and professionals' health as well as influence professional performance in the emergency ward. Sound pressure levels of the helicopter and cast saw reach high hearing hazard levels, requiring professionals to use individual protection equipment, and point to the need for creation and implementation of effective control measures of noise levels in emergency wards.
\end{abstract}

\section{Introduction}

Technology is highly valued, especially in health care for patients with serious conditions, and sometimes technology is necessary to save lives. These technologies contribute to increased noise, making environments uncomfortable. ${ }^{1}$ The occupational risk due to high levels of noise in the hospital environment has been recognized, and at the suggestion of the National Agency of Sanitary Surveillance of the Ministry of Health, ${ }^{2}$ evaluation and control of noise in hospital areas is recommended, especially in areas with compressed air and

received

May 12, 2014

accepted after revision

June 1, 2014

published online

August 25, 2014 vacuum generation in maintenance areas, workshops, and laundries.

The recommendation for hospital areas is that the noise level should not exceed $55 \mathrm{~dB}^{3}$ Levels above this value are considered uncomfortable and can cause extra-auditory effects in the body in general. Although there is variation from individual to individual, people are directed to avoid exposure to noise levels that exceed 85 to 90 sound pressure level ambiance $[\mathrm{dBA}] .^{3}$

The Regulatory Norm (NR-17) covers aspects related to environmental conditions and the organization of
Copyright $\odot 2015$ by Thieme Publicações License terms Ltda, Rio de Janeiro, Brazil
DOI http://dx.doi.org/

10.1055/s-0034-1387165. ISSN $1809-9777$.

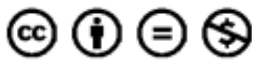


workplaces. ${ }^{4}$ In work spaces where there is constant attention and performance using intellectual activity, NR-17 recommends comfort conditions, which includes the noise level, following the provisions of NBR 10152/87. ${ }^{3}$

According to the World Health Organization, ${ }^{5}$ among the critical effects of noise in hospitals are communication interference, including with warning signs of annoyance and sleep disturbance. Therefore, this Norm recommends that the equivalent sound pressure level (Leq) not exceed 35 A-weighted decibel scale (dBA) in rooms where patients are treated and observed. Special attention to noise levels in the intensive care unit (ICU) and in operating rooms is recommended. ${ }^{5}$

However, studies in hospitals that analyzed the noise in various areas such as the ICU, ${ }^{6-12}$ emergency room (ER), material center, surgical center, pharmacy, pediatrics, kitchen, laundry room, ${ }^{10}$ corridors, and nursing station ${ }^{13}$ showed high levels. The noise was associated with conversation among professionals, movement of people, and various hospital medical equipment, including acoustic alarms, which are essential to alert professionals to changes in clinical status of patients or malfunctioning devices. ${ }^{6-13}$ In addition, noise hampers professionals' concentration. ${ }^{14}$ It is recommended that emergency department team members be encouraged to better know the noise of their own work environment. ${ }^{15}$

In this context, the ER deserves attention because nowadays it contains various hospital medical equipment, a large team of professionals, accident victims and their families, and rescue vehicles, thereby increasing the ambient noise.

The present study aimed to evaluate the ambient sound in the ER of a general hospital, known for its trauma care, in the city of Curitiba, Paraná.

\section{Methods}

This is a descriptive cross-sectional study conducted in the ER of a general hospital known for its trauma care in the city of Curitiba, Paraná in 2011. The project was approved by the ethics committee of the hospital under number 167/2010.

Assessments followed the procedures outlined by the Standard for Occupational Hygiene of FUNDACENTRO to characterize the exposure of all workers considered. ${ }^{16}$ The instruments used to assess the noise were a Bruel \& Kjaer (Denmark) brand type 2230 sound pressure level meter, carried by the evaluator, and a Bruel \& Kjaer type 4230 sound level calibrator, all property of FUNDACENTRO/PR. The meter was properly calibrated before the tests.

The minimum (Lmin), maximum (Lmax), and Leq were evaluated and expressed in decibels, compensated for on the dBA. Measurements were taken at 10 sites inside the ER: the Advanced Life Support (ALS) room, ALS anteroom, nursing station, in front of the nursing station, suture room, main corridor, observation room, in front the service windows, reception, tomography and X-ray viewing room, some equipment, and patient transport helicopter.

The steps followed a sequence, with a 2- minute, 30 second evaluation at each site. After going through all the selected locations, the evaluation was done three more times, so that four measurements were taken at each site, with maximum, minimum, and Leq, in the mornings between $7 \mathrm{Am}$ and $1 \mathrm{PM}$, in the afternoon between $1 \mathrm{PM}$ and 7 PM, and at night between 7 PM and 7 Aм. During the evaluation, time was measured by a stopwatch and notes were taken about events that altered the measurements. For the helicopter and equipment, a single measurement was performed in the afternoon. The data are presented in table format.

\section{Results}

- Table 1 shows the noise levels in the ER. The greatest value of Leq dBA was recorded in the ALS anteroom (68.8 dBA) during the night, and the lowest value of Leq $\mathrm{dBA}$ occurred in the suture room (56.6 dBA) in the morning. The lowest Lmin was detected in the suture room (44.1 dBA) at night. The room was empty. However, we measured the background noise and the highest Lmin occurred in the ALS (59.5 dBA) in the morning. The highest Lmax was detected in the suture room (96.3 dBA) in the afternoon in the presence of four patients and a crying child, and the lowest Lmax occurred in front of the service windows (73.2 dBA). In the 10 areas assessed, the highest Leq dBA frequency occurred in the afternoon.

- Table 2 presents the levels of continuous Leq dBA noise found in various equipment operating in the ER. Among the equipment, the cast saw had the highest measurements (90.0 dBA) and the oximeter the lowest (61.0 dBA). The noise of the helicopter was $119 \mathrm{dBA}$, running for 20 minutes on the landing pad.

\section{Discussion}

This study evaluated the sound environment in the ER of a general hospital known for its trauma care in the city of Curitiba, Paraná. The results presented in -Tables 1 and 2 show that Leq values were above the acceptable comfortable noise levels for hospital environments. ${ }^{3,4}$

Of the various noise sites evaluated ( $\mathbf{- T a b l e ~} \mathbf{1}$ ), the lowest Leq was measured in the suture room (56.6 dBA) and the highest in the ALS anteroom (68.8 dBA). Accident victims arrive in this area, and it is also a meeting place for various professional teams that send and receive patients, causing movement of people and equipment and the need for oral communication, which increases sound pressure level.

Few studies analyze the noise in ERs. However, one study evaluating an ER identified the highest Leq, ranging from 65 to $73 \mathrm{dBA}$, in the triage area. ${ }^{17}$ The authors considered the noise in the ER sufficiently high and worrisome because the health staff works with a sense of urgency and needs to rely on oral communication. ${ }^{17}$ In another study, when assessing areas of a teaching hospital, such as the ER, ICU, hospital medical-surgical floors, and a nursing home, noise levels in the hospital ranged from 55 to $70 \mathrm{dBA}$. The authors reported the highest level was in the ER and concluded that the human factor is a major source of noise pollution. ${ }^{18}$

A study in four emergency units in Phoenix, Arizona, found in hospital A the lowest noise intensity of $55.9 \mathrm{dBA}$, 
Table 1 ER noise levels at different periods of the day

\begin{tabular}{|c|c|c|c|c|c|}
\hline Area & Period & $\begin{array}{l}\text { Continuous } \\
\text { noise } \\
\text { [dBA Leq] }\end{array}$ & Lmin & Lmax & Notes \\
\hline \multirow[t]{3}{*}{ 1. ALS } & Morning & 64.7 & 59.5 & 80.7 & $\begin{array}{l}\text { Radio on; AC on; } 1 \text { patient sleeping without } \\
\text { respirator; } 2 \text { workers; }\end{array}$ \\
\hline & Afternoon & 61.5 & 50.9 & 79.7 & $\begin{array}{l}\text { 4-6 patients; } 4 \text { monitors; } 2 \text { patients on respi- } \\
\text { rator; AC off }\end{array}$ \\
\hline & Night & 64.1 & 56.4 & 85.3 & AC on; 1 patient; 3 workers \\
\hline \multirow[t]{3}{*}{ 2. ALS anteroom } & Morning & 61.8 & 53.5 & 78.2 & No patients (clothing collection) \\
\hline & Afternoon & 68.3 & 55.0 & 79.9 & 2 patients; 3 health care teams \\
\hline & Night & 68.8 & 54.1 & 83.0 & 1 patient; 6 health care teams \\
\hline \multirow[t]{3}{*}{ 3. Nursing station } & Morning & 63.2 & 50.4 & 80.4 & 4 health care teams; telephone ringing \\
\hline & Afternoon & 67.3 & 55.2 & 79.6 & 5 health care teams \\
\hline & Night & 63.8 & 50.5 & 79.8 & 4-5 health care teams \\
\hline \multirow[t]{3}{*}{ 4. In front of nursing station } & Morning & 62.0 & 50.8 & 77.2 & 3-6 people without patient on gurney \\
\hline & Afternoon & 65.8 & 54.2 & 77.0 & 3 patients on gurney \\
\hline & Night & 63.6 & 51.3 & 81.6 & 5 people; 3 patients on gurney; 2 visitors \\
\hline \multirow[t]{3}{*}{ 5. Suture room } & Morning & 56.6 & 44.2 & 68.9 & Empty room; background noise \\
\hline & Afternoon & 64.1 & 48.2 & 96.3 & 4 adult patients; 1 patient (child) crying \\
\hline & Night & 60.4 & 44.1 & 82.2 & 2 patients; 1 visitor; 1 doctor (garbage lid noise) \\
\hline \multirow[t]{3}{*}{ 6. Main corridor } & Morning & 62.3 & 50.6 & 76.6 & Few people in corridor \\
\hline & Afternoon & 66.3 & 53.8 & 85.6 & Many people in corridor \\
\hline & Night & 62.0 & 49.6 & 78.7 & 10 adults sitting \\
\hline \multirow[t]{3}{*}{ 7. Observation room } & Morning & & & & CLOSED \\
\hline & Afternoon & 62.0 & 47.4 & 80.6 & 4-5 patients; $2-3$ visitors; 1 monitor on \\
\hline & Night & & & & CLOSED \\
\hline \multirow[t]{3}{*}{ 8. In front of service window } & Morning & 60.2 & 48.5 & 77.8 & 7 patients at windows \\
\hline & Afternoon & 63.4 & 50.6 & 79.9 & 3 patients; 1 worker \\
\hline & Night & 62.2 & 50.9 & 73.2 & Patients with visitors \\
\hline \multirow{3}{*}{$\begin{array}{l}\text { 9. Imaging exam room } \\
\text { (tomography; } X \text {-ray) }\end{array}$} & Morning & 60.8 & 55.5 & 77.5 & 1 worker attending; $A C$ on \\
\hline & Afternoon & 63.6 & 55.4 & 85.0 & 3 workers \\
\hline & Night & 59.0 & 49.7 & 75.8 & 1 worker \\
\hline \multirow[t]{3}{*}{ 10. Reception } & Morning & 64.5 & 49.8 & 83.0 & 3-4 workers; client movement \\
\hline & Afternoon & 66.8 & 46.0 & 86.0 & $\begin{array}{l}4 \text { workers; client movement at counter; falling } \\
\text { object }\end{array}$ \\
\hline & Night & 66.8 & 50.0 & 81.1 & Client movement; drawer shut quickly \\
\hline
\end{tabular}

Abbreviations: AC, air conditioner; ALS, Advanced Life Support; ER, emergency room; Leq, average equivalent level; dBA, compensated for on the Aweighted decibel scale; Lmin, minimum sound pressure; Lmax, maximum sound pressure.

with an average of $69.1 \mathrm{dBA}$ and a peak of $76.6 \mathrm{dBA}$; hospital $\mathrm{B}$, lowest intensity $65.5 \mathrm{dBA}$, averaging $70.1 \mathrm{dBA}$ and a peak of 73.4 dBA; hospital $C$, the lowest value 71.1 dBA, with an average of $73.0 \mathrm{dBA}$ and peak of $75.6 \mathrm{dBA}$; and hospital $\mathrm{D}$, lowest value $65.3 \mathrm{dBA}$, an average of $66.6 \mathrm{dBA}$, and a peak of $75.2 \mathrm{dBA}$. The author concluded that these levels are sufficient to cause deleterious psychological and secondary physical effects to the team members. Also, the author reported that reducing the level of ambient noise can improve patient care, reduce stress, and increase employee job satisfaction. ${ }^{15}$

The Leq values found in the ER reception area ( - Table 1 ) ranged from 64.5 to $66.8 \mathrm{dBA}$ and are in accordance with the noise assessment study that evaluated the various internal areas of hospital service; the reception area of the ER measured 64.2 dBA. $^{10}$

In all sectors, the Leq in the afternoon was higher, ranging from $61.5 \mathrm{dBA}$ to $68.3 \mathrm{dBA}$ in the ALS and ALS anteroom. 
Table 2 Noise level of equipment and transport

\begin{tabular}{|l|l|l|}
\hline $\begin{array}{l}\text { Equipment and } \\
\text { transport }\end{array}$ & $\begin{array}{l}\text { Continuous } \\
\text { noise [dBA Leq] }\end{array}$ & $\begin{array}{l}\text { Alarm noise } \\
\text { [dBA Leq] }\end{array}$ \\
\hline Respirator on & 66.0 & 74.0 \\
\hline Oximeter on & 61.0 & 70.0 \\
\hline Oxygen on & 72.0 & - \\
\hline AC on & 68.0 & - \\
\hline Phone ringing & 75.0 & - \\
\hline Cast saw & 90.0 & - \\
\hline Helicopter & 119.0 & - \\
\hline
\end{tabular}

Abbreviations: AC, air conditioner; Leq, average equivalent level; dBA, compensated for on the A-weighted decibel scale.

However, a higher Leq variation of 68.8 dBA occurred in a single sector at night. The data are in accordance with other findings, ${ }^{19}$ where the afternoon shift was considered the loudest, even including the neonatal ICU (NICU).

However, this study did not corroborate other studies. ${ }^{20,21}$ This divergence can be explained because the activities performed in ERs are different from routines performed in other hospital areas. The environment of the ER does not have a certain time of increased noise due to several activities that happen according to the demand of the moment.

An unstructured observational study in a surgical inpatient unit of 28 beds, made up of four rooms with six beds and one with four beds, concluded that the morning noise level was higher because of the presence of the majority of health professionals and the routine work in the wards (hygiene, changing linens, admission and transfer of patients, referral for surgery as well as emergency admissions). ${ }^{20}$ Likewise, in another study conducted in an NICU, ${ }^{21}$ the noise level was higher in the morning, due to the conversations between people and the jet of water from the hand washing sink. In the present study, the highest Leq occurred in the ALS anteroom. This situation can be explained by the activities at this site (i.e., reception of accident victims, meetings of various professionals, transporting of victims). And because it is a teaching hospital, there is also much movement of health care students adding to the noise.

We observed that noise levels altered slightly, reaching maximum values well above $80 \mathrm{dBA}$ as stated in - Table 1. This situation was observed when objects fell, materials and equipment such as transport stretchers and dressing tables were manipulated, garbage carts were transported, waste receptacle lids or drawers were opened and closed, clipboards were handled, loud conversations were had, children cried, patients/families or professionals used loud voices, patients were located for examinations, phones rang, and emergency alarms buzzed in equipment such as respirators and monitors (-Table 2).

A similar study regarding noise in the hospital workplace observed changes in noise due to periodic disturbances caused by the increased flow of people talking loudly, including students, teachers, clients, caregivers, and workers. Frequent noise caused by trolleys, stretchers, wheelchairs, and phones was also detected. The study evaluated the comfort levels of workers in a hospital ward, as determined by NR-174, and found that the values were $50 \mathrm{dBA}, 51 \mathrm{dBA}$, and $56 \mathrm{dBA}$ in each ward, ${ }^{22}$ which were lower than those detected in the ER.

Noise above the levels considered comfortable can impact overall health and lead to nonperception of important sounds. In a study in which the noise ranged from 52.35 to $84.60 \mathrm{dBA}$, nursing professionals had hearing complaints like ringing and extra-auditory problems such as irritation, sleep disturbance, headaches, and poor concentration. ${ }^{23}$

An environment in which the minimum level of background noise exceeds 45 to $50 \mathrm{dBA}$ will require people to raise their voices by $\sim 30 \mathrm{dBA}$ above the noise, so that a difference between the two signals occurs and understanding can happen ${ }^{24}$; this situation will require very high levels of speech at around $80 \mathrm{dBA}$ like the values found in - Tables 1 and 2, which cause discomfort and fatigue, leading to difficulty concentrating. ${ }^{24}$ This is a worrisome situation that interferes with the performance of professional tasks in the ER environment.

In -Table 2, the Leq value for the helicopter arrival corresponds to a high risk for hearing professionals who are not properly using protective equipment. The daily maximum permissible exposure values are $115 \mathrm{dBA}$ for 7 minutes; the cast saw at $90 \mathrm{dBA}$ corresponds to a maximum of 4 hours of daily exposure. ${ }^{25}$

Besides hearing risk, researchers report that high noise levels can cause behavioral disorders, and sound pressure intensity of $65 \mathrm{dBA}$ can affect the hypothalamus and pituitary, raising the levels of secretion of epinephrine, norepinephrine, and corticosteroids as well as increasing blood pressure and changing heart rate and peripheral vasoconstriction. $^{7,12}$

Therefore, it appears that the noise levels present in the ER can impact the overall health of the population. The implementation of program promoting health and prevention is recommended. Preventive/educational actions are strongly recommended for early identification or avoidance of the onset of signs and symptoms related to noise exposure to provide a better quality of life to health care teams. It is necessary to implement effective measures to control noise in the ER, as well as providing for the satisfactory use of ear protection equipment for employees exposed to noise. Workshops are important to educate the team regarding self-care and improvements in health and work.

\section{Conclusion}

In all assessed points, noise levels were above the comfort levels recommended by the Brazilian Association of Technical Standards (1987), which may harm users' and professionals' health as well as influence professional performance in the emergency ward. Leq levels of helicopter and cast saw entail high hearing hazard, requiring professionals to use individual protection equipment, and point to the need of creation and implementation of effective control measures of noise levels in emergency wards. 


\section{References}

1 Diniz INA, Junior WMG, Araujo GW. Determinação dos níveis de ruído nas unidades de terapia intensiva de dois hospitais de Belo Horizonte, visando uma melhoria na qualidade de vida. Anais do VIII Congresso de Ecologia do Brasil; 2007 Setembro 23-28, Caxambu-MG. Available at: www.seb-ecologia.org.br/viiiceb/pdf/ 433.pdf. Accessed September 23, 2009

2 ANVISA.. Agência Nacional de Vigilância Sanitária. Segurança no ambiente hospitalar.[Manual na Internet]. [s.d.] Available at: http://www.anvisa.gov.br/servicosaude/manuais/seguranca_ hosp.pdf. Accessed May 9, 2011

3 ABNT. Associação Brasileira de Normas Técnicas-NBR 10152. Níveis de ruído para conforto acústico. Rio de Janeiro, Brazil; 1987 Available at: http://www.semace.ce.gov.br/wp-content/uploads/2012/01/Avalia\%C3\%A7\%C3\%A3o+do+Ru\%C3\%ADdo+em+\% C3\%81 reas+Habitadas.pdf. Accessed August 05, 2014

4 MANUAIS DE LEGISLAÇÃO.. Lei n. ${ }^{\circ}$ 6514, de 22 de dezembro de 1977. NR-17. p. 496. 61 ed. São Paulo, Brazil: Atlas; 2007

5 WHO. World Health Organization. Guidelines for Community Noise. Noise sources and their measurement. 1999. Available at: http://www.who.int/docstore/peh/noise/guidelines2.html. Accessed August 10, 2011

6 Pereira RP, Toledo RN, Amaral JLG, Guilherme A. Qualificação e quantificação da exposição sonora ambiental em uma unidade de terapia intensiva geral. Rev Bras Otorrinolaringol (Engl Ed) 2003; 69(6):766-771

7 Carvalho WB, Pedreira MLG, Aguiar MAL. Nível de ruídos em uma unidade de cuidados intensivos pediátricos. J Pediatr 2005;81(6): 495-498

8 Rodarte MDO, Scochi CGS, Leite AM, Fujinaga CL, Zamberlan NE, Castral TC. O ruído na manipulação das incubadoras: implicações para o cuidado de enfermagem. Rev Latino-am Enfermagem 2005; 13(1):79-85

9 Otenio MH, Cremer E, Claro EMT. Intensidade de ruído em hospital de 222 leitos na $18^{\mathrm{a}}$ Regional de Saúde-PR. Rev Bras Otorrinolaringol (Engl Ed) 2007;73(2):245-250

10 Zamberlan NE, Ichisato SMT, Rodarte MDO, Fujinaga CI, Hass VJ, Scochi CGS. Ruído em uma unidade de cuidado intermediário neonatal de um hospital universitário. Ciênc Cuid Saúde 2008; $7(4): 431-8$

11 Ichisato SMT, Scochi CGS. Ruídos na unidade de cuidado intensivo neonatal durante as passagens de plantão(enfermagem e/ou médica) e visita médica. Cienc Cuid e Saúde 2006;5 (suplemento)127-33

12 Macedo ISC, Mateus DC, Costa EMGC, Asprino ACL, Lourenço EA. Avaliação do ruído em Unidades de Terapia Intensiva. Braz J Otorhinolaryngol 2009;75(6):844-846
13 Costa GL. Ruído no contexto hospitalar: impacto na saúde dos profissionais de enfermagem [Dissertação de Mestrado em Distúrbio da comunicação em linguagem e audição]. Curitiba, Brazil: Universidade Tuiuti do Paraná; 2011

14 Stumm EMF, Scapin D, Fogliatto L, Kirchner RM, Hildebrandt LM. Qualidade de vida, estresse e repercussões na assistência: equipe de enfermagem de uma unidade de terapia intensiva. Rev Textos Contextos 2009;8(1):140-155

15 Buelow M. Noise level measurements in four Phoenix emergency departments. J Emerg Nurs 2001;27(1):23-26

16 NHO-01. Norma de higiene ocupacional procedimento técnico. FUNDACENTRO: Ministério do trabalho. 2001 Available at: file:/// C:/Users/Toshiba/Downloads/NHO01.pdf Accessed August 05, 2014

17 Orellana D, Busch-Vishniac IJ, West JE. Noise in the adult emergency department of Johns Hopkins Hospital. J Acoust Soc Am 2007;121(4):1996-1999

18 Bharathan T, Glodan D, Ramesh A, et al. What do patterns of noise in a teaching hospital and nursing home suggest? Noise Health 2007;9(35):31-34

19 Aurélio FS, Tochetto TM. Mensuração do ruído em uma Unidade de Terapia Intensiva Neonatal. Acta Pediátrica Portuguesa. 2010; 41(2):64-68

20 Christensen M. Noise levels in a general surgical ward: a descriptive study. J Clin Nurs 2005;14(2):156-164

21 Cardoso MVLM, Chaves EMC, Bezerra MGA. Ruídos e barulhos na unidade neonatal Rev Bras Enferm, Brasília [periódico online] 2010;63(4): 561-566. Available at: http://www.scielo.br/pdf/reben/v63n4/10.pdf. Accessed December 16, 2011

22 Alves PM. Aplicação da NR 17 em uma enfermaria de uma Santa Casa de Misericórdia: um estudo de caso [mestrado]. Bauru, Brazil: Universidade Estadual Paulista; 2010

23 Costa GL. Ruído no contexto hospitalar: impacto na saúde dos profissionais de enfermagem. Rev Soc Bras Fonoaudiol [periódico online]. 2011;16(4):492. Available at: http://www.scielo.br/pdf/ rsbf/v16n4/v16n4a23.pdf. Accessed August 05, 2014

24 Ribas A. Reflexões sobre o ambiente sonoro da cidade de Curitiba: a percepção do ruído urbano e seus efeitos sobre a qualidade de vida de moradores dos setores especiais estruturais[Tese de doutorado em Meio Ambiente e Desenvolvimento da Universidade Federal do Paraná]. Curitiba, Brazil: Universidade Federal do Paraná; 2007

25 Brasil. Ministério do Trabalho. Limite de tolerância. Portaria 3214 de 08 de junho de 1978-NR 15 Anexos 1 e 2 [Norma regulamentadora na internet]; 1978 June. Available at: http://portal.mte.gov.br/legislacao/norma-regulamentadora-n-15.htm. Accessed September 28, 2011 